\title{
A SHORT BIBLIOGRAPHY OF GENETIC RESEARCH PUBLISHED IN JAPAN, 194I-1948†
}

\author{
Compiled by LUONG DINH CUA \\ Laboratory of Genetics, Biological Institute, Kyoto Imperiol University
}

Received I3.iv.49

(Jap.) papers, most of which are in résumé-form, in Japanese with English or German titles only.

* Original papers in Japanese with English or German résumé.

( ) Titles in brackets are of original papers published entirely in Japanese.

ABE, S., 1942. (Parthenogenesis induced by the pollination of diploid pollen.) Ikusyu-kenkyu, I, I35-1 37 .

Arshima, T., 1941. Studies of mitosis and meiosis in comparison. II. Chromosome structure in the spiral stage and anaphase in mitosis as revealed by means of a maceration method. Cytologia, II, 429-435.

Amano, Y.,* 1943. Sex and chromosomes of Taxus cuspidata, Sieb. et Zucc. Fap. Four. Genet., 19, 102-103.

Asana, J. J., and Niryama, H., 1942. A chromosomal survey of some Indian insects. IV. On the sex chromosomes of some species of beetles (Coleoptera). Cytologia, 12, 187-205.

Asano, K.,* 1947. Inheritance of the compressed segments in silkworms. $7 a p$. Four. Genet., 22, 88-92.

Chino, M.,* 1941. New mutants in Drosophila virilis virilis. (1). Fap. Four. Genet., I7, $185-206$.

FujII, S., 1942. Further studies on the salivary gland chromosome of Drosophila virilis. Cytologia, 12, 435-459.

Fukuda, H., and TAkemura, M.,* 1943. Genetical studies of Trichogramma. Jap. Four. Genet., 19, 275-281.

FukUDA, S.,* 1941. Genes and gene-hormones concerning pigment formation in serosa of the silkworm. Jap. Four. Genet., 17, 97-108.

Fukushima, E., 1945. Cytogenetic studies on Brassica and Raphanus. I. Studies on the intergeneric $\mathrm{F}_{1}$ hybrids between Brassica and Raphanus. Four. Dept. Agri. Kyushu Imp. Univ., Vol. 7, 9, 281-400.

Funushima, E., 1948. Cytogenetic studies on the Pomoidea. I. Chromosome number of the cultivated varieties of apples, European pears, and Japanese pears cultivated in Japan. Four. Fac. Agri. Kyushu Univ., Vol. 9, No. I.

Furuhata, T. (Jap.), i 947 . On the inheritance of the Rh gene. Fap. Four. Genet., 22, 6-7.

Furuhata, T., and Miki, T. (Jap.), 1948. A diagnosis of the parent-child relationship by blood groups, finger and palm prints. Jap. Jour. Genet., 23, 10.

HAGA, T., 1942. Nucleolus-chromosome relationship in Paris verticillata M. B., with special reference to the presence and absence of a satellite. Cytologia, I2, 479-485.

HAGA, T. (Jap.), 1942. Geographical distribution of Trilliacere plants in relation to polyploidy. Fap. Four. Genet., 18 , 168.

HAGA, T., 1943. A reciprocal translocation in Lilium Hansonii Leicht. Cytologia, $13,19-25$.

$\dagger$ Abbreviated by the editor. 
HAGA, T., 1944. Meiosis in Paris. I. Mechanism of Chiasma formation. Four. Fac. Sci. Hokkaido Univ., Series V, Vol. V, 3, 1 $21-198$.

HAGA, T. (Jap.), 1946. Chromosome mutation under the low temperature condition. Jap. Jour. Genet., $21,87$.

HaGA, T., and Kuribayashi, M. (Jap.), 1947. A study of natural populations by means of differential reaction of the chromosomes (a preliminary note). Fap. Four. Genet., 22, 8-9.

Haga, T., and Kuribayashi, M. (Jap.), 1947. Genom analysis in the genus Trillium on the basis of differential reaction of the chromosomes. Fap. Four. Genet., $22,8$.

HAGA, T., and KuRIBAyAshi, M. (Jap.), r 948 . An analysis of the natural populations of Trillium kamtschaticum Pall. Fap. Four. Genet., 23, 12-13.

Hagiwara, T., and Oomura, Y.,* i 947 . On linkage in Capsicum annum L. Jap. Four. Genet., Supp., Vol. I, 87-95.

HARA, S., * 1944. Genetical studies on the chlorophyll characters in rice. I. Occurrence and inheritance of chlorina types. Fap. Four. Genet., 20, I5-19.

HARA, S., ${ }^{*}$ 1946. Genetical studies on the chlorophyll characters in rice. II. Occurrence and inheritance of xantha types. Fap. Four. Genet., 21 , I-9.

HARA, S., ${ }^{*}$ I 946 . Genetical studies on the chlorophyll characters in rice. III. Occurrence and inheritance of albino-types. Fap. Four. Genet., 2I, I 5-21.

Harada, I.,* (Jap.), 1942. Chromosome studies on Potamogeton. Fap. Four. Genet., $18,92-96$.

Harada, I.,* (Jap.), 1943. Die Karyotyp der Gattung Najas. Fap. Four. Genet., I9, I 20-1 21

Hashimoto, H., r94I. Genetical studies on the tetraploid female of silkworm. IV. The embryonal mortality and sex ratio in the $F_{1}$ hybrid of a tetraploid female with a diploid male. V. Heredity of gynandromorphism. Bull. Imp. Sericult. Exp. Stat., ro.

HayASI, B., ${ }^{*}$ 1 942 . A new hereditary type of rumplessness in the fowl. Fap. Four. Genet., $18,254-260$.

HAYASI, B., * I 943 . On the inheritance of polydactyly in the cross of White Leghorn and Silky fowl. Fap. Four. Genet., 19, 243-247.

HAYASI, B.,* 1943. A pedigree of ear pit (Fistula auris congenita). Jap. Four. Genet., 19, 86-87.

Нrокı, K., 1942. Zytologische Untersuchungen über das Flimmerepithel der menschlichen Trachea u.s.w. Cytologia, 12, 326-346.

Hiraoka, T., I94I. Studies of mitosis and meiosis in comparison. III. Behaviour of chromonemata in the pre-leptotene stage in meiosis. Cytologia, II, 473-482.

Hiraoka, T., r94I. Studies of mitosis and meiosis in comparison. IV. A contribution to the study of the origin of the "bouquet" and its formation. Cytologia, II, 483-492.

HiraOKa, T.,* 1947. Effect of various chemicals upon the seedlings of Raphanus sativus. A study on the method of producing polyploid. Seibutu, Supp. No. I, 20-24.

Hiraoka, T., 1947. Enzyme activity in Lilium anthers. Memoirs Coll. Sci. Kyoto Univ., Series B, Vol. XIX, No. I, Art. 6.

Hirayoshi, I., 194I. (An induction of polyploid forest trees by treatment with colchicine.) Ziho, 2, 34-36 (Kihara Institute for Biological Research).

Hirayoshi, I., 1942. (Studies on induced polyploids in forest trees.) Bot. and Zool., Io, 766-768.

Hirayoshi, I.,* r 942. Cytological and genetic studies on forest plants. I. Chromosome numbers in some conifers. Bot. and Zool., ro, 766-776.

Hirayoshi, I., Nakamura, Y., and Kano, T.,* i 943 . Cytological and genetic studies on forest plants. II. Chromosome conjugation in pollen mother cells and pollen fertility of Aiguro-matu (Pinus densi, Thunbergii Uyeki). Seiken Ziho, 2, 9o-96 (Kihara Inst. Biol. Res.). 
Hirayoshi, I., and Nakamura, Y.,* 1943. Chromosome number of Sequoia sempervirens. Bot. and Zool., II, 73-75.

Hosino, Y.,* 1943. Genetical studies of the lady-bird beetle, Harmonia azyridis Palles. VIII. Fap. Four. Genet., 19, 258-265.

Hosoda; T., 1946. (Fertility of amphidiploids between Brassica and Raphanus.) Agric. and Hort., 21, 515.

Hosoda, T., 1946. (On the dimension of $F_{1}$ seeds in crosses among Brassica, Sinapis and Raphanus. Agric. and Hort., 2I, 516.

IInuma, Y., 1941. Variegation in Taraxacum platycarpum. Fap. Four. Genet., 17, 229-230.

InABA, F., ${ }^{*}$ I 94 I. Polyploidy in Habrobracon induced by colchicine treatment. Cytologia, 12, 66-78.

InABA, F., ${ }^{*}$ 1944. Genetical studies on Habrobracon pectinophore. I. Sex-linked inheritance and sex-determination. Fap. Four. Genet., 20, 27-47.

InABA, F., ${ }^{*}$ 1944. Genetical studies on Habrobracon pectinophore. II. Mutant characters and their mode of inheritance. Fap. Four. Genet., 2o, 48-54.

InARIYAMA, S. (Jap.), I948. The origin of the Japanese Lycoris plants. Fap. Four. Genet., 23, I 5-16.

INor, S., 1944. Embryological studies on Turbinaria and Cystophyllum. Four. Fac. Sci. Hokkaido Imp. Univ., Series V, Vol. V, 3, 197-2 I4.

IshinARA, T. (Jap.), 1946. Taxonomy and genetics of the swallow tail butterfly, Papilio memnon Linné. Fap. Four. Genet., 21, 80.

Itikawa, N.,* I 947. Genetical and embryological studies on the " new additional crescent" silkworm, Bombyx Mori L. III. Fap. Four. Genet., Supp. Vol. I, 59-66.

Iто, T., 194I. Ueber den Golgiapparat und die Mitochondrien der Spermatogonien sowie Spermatozyten des Menschen, nebst Bemerkungen der Riesenspermatogonien. Cytologia, II, 436-451.

Iто, T., 1942. Chromosomen und Sexualität von der Araceæ. I. Somatische Chromosomenzahlen einiger Arten. Cytologia, 12, 313-325.

Kasahara, K. (Jap.), 1948. Studies on the mutable genes of Pharbitis purpurea. Fap. Four. Genet., 23, 18.

Katayama, Y., and Fujino, I.,* 1947. Two new strains of upland cotton in Southern Manchuria. Fap. Four. Genet., 22, 72-77.

Kawabe, M. (Jap.), 1947. Notes on the chromosomes of Bradybena (Ezoheilix) gainesi. La Kromosomo, 3-4, 133-134.

KaWAGuchi, E., and SuzuKI, M. (Jap.), i 947 . Cytological proof of the translocation involving the second and $\mathrm{W}$ chromosomes of the silkworm. Fap. Jour. Genet., 22, 14 .

Kawakami, R., and Matsumura, Y.,* (Jap.), 1942. Mathematical law controlling the distribution of finger prints. Fap. Four. Genet., 18, 96-98.

Kawamura, T., 1941. Triploid frogs developed from fertilized eggs. Proc. Imp. Acad., 17, 523-526.

Kawamura, T. (Jap.), i 943 . Breeding experiments between triploid males and diploid females of Rana nigromaculata. Fap. Four. Genet., 19, 122-1 23.

Kawamura, T.,* (Jap.), 1946. On the fertility of species hybrids of Triturus

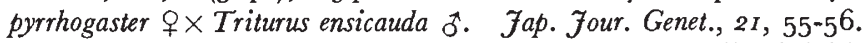

Kawamura, T.,* (Jap.), 1946. On some characters of allotriploid newts, Triturus. Fap. Four. Genet., 21, I I 5-1 16.

KAWARA, E., 194I. (Some modifications of rice plants by treatment with chloralhydrate.) Agric. and Hort., 16, I 787-1 789.

Kichijo, H., ${ }^{*}$ i 942 . Chromosomes of Oligotoma japonica (Embioptera). Fap. Four. Genet., 18 , 196-197.

KICHIJO, H., ${ }^{*}$ I 942 . On the chromosomes of some species of the Zygopterous dragonflies (Odonata, Zygoptera). Fap. Four. Genet., 18, 273-276.

Kida, F., and Kodama, T. (Jap.), 1947. Studies on the continuous distribution of human genetical characteristics. Fap. Jour. Genet., 22, I4. 
Krhara, H., und Matsumura, S., I94I. Rückkreuzung des Bastards Ae. caudata $\times A e$. cylindrica zu den Eltern und seinen Nachkommen. Cytologia, II, 493-506.

Krhara, H., und Kishimoto, E.,* ${ }^{*} 942$. Bastarde zwischen Setaria italica und S. virilis. Bot. Mag. Tokyo, 56, 662, 62-67.

Krhara, H., und Matsumura, S., 1942. Ueber die Univalentenelimination in den verschiedenchromosomigen Nachkommen des pentaploiden TriticumBastards. Fap. Four. Bot., 12, 225-236.

Kinara, H., und Kishimoto, E., ${ }^{*}$ I942. Embryologische Studien über die Entstehungsweise der Haploiden durch verspätete Bestäubung bei Triticum monococcum var. Vulgare, Seiken Ziho, I, I-9.

Kihara, H., und Hirayoshi, I.,* I 942 . Entwicklung des Pollenkorns bei Oryza sativa L. Agric. and Hort., 17, 685-69o.

Kihara, H., und Yamada, I.,* I942. Ein Fall von Plasmonwirkung auf das artfremde Genom. Seiken Ziho, $1,38-45$.

Krhara, H. (Jap.), r 943 . Die durch Röntgenbestrahlung induzierten Komplexmutationen bei Triticum monococcum. Fap. Four. Genet., 19, I 36 -1 38.

Kihara, H., ${ }^{*}$ r 943 . Genetic studies in Setaria Beauv. Seiken Ziho, 2, I-3.

KiharA, H., and Kondo, N., ${ }^{*}$ r 943 . Studies on amphidiploids of Aegilops caudata $\times$ Ae. umbellata induced by colchicine. Seiken Ziho, 2, 24-42.

Kinara, H., und Matsumura, S., ${ }^{*}$ I 943 . Röntgenstrahleninduzierte Chromosomenaberranten bei Aegilops cylindrica Host. Seiken Ziho, 2, 83-89.

Kinara, H.,* r944. Chromosome conjugation in a rose hybrid, Rosa multiflora $\times$ R. rugosa. Fap. Jour. Genet., 20, 55-58.

Krhara, H.,* 1944. A linkage group in Einkorn-wheat. Fap. Four. Genet., 20, $64-67$.

KIHARA, H., ${ }^{*}$ I 946 . Maturation division in $\mathrm{F}_{1}$ hybrids between Triticum dicoccoides $\times$ Aegilops squarrosa. La Kromosomo, I, 6-I I.

Kinara, H., and Yamashita, Y.," ${ }^{*}$ 1947. Genetic studies on mutations induced by X-ray in Eikorn-wheat. I. Seiken Ziho, 3, Part 2, 29-39.

Kinara, H., and Yamashita, Y., ${ }^{*}$ 1947. A preliminary investigation for the formation of tetraploid watermelons. Seiken Ziho, 3, Part 3, 89-92.

Kinara, H., and Nishiyama, I., ${ }^{*}$ I947. An application of sterility of autotriploids to the breeding of seedless watermelons. Seiken Ziho, 3, Part 3, 93-г o3.

KinarA, H. (Jap.), i948. Methods for transplantation of the nucleus. Fap. Four. Genet., 23, 20-2 I.

Kimura, M.,* (Jap.), I946. Karyotype analysis in Lilium and Cardiocrinum. Jap. Four. Genet., 21, I I 8-I I 9 .

Kodama, T. (Jap.), r 948 . A study about the family similarity of the handwriting. Fap. Four. Genet., 23, 22.

Komai, T., and TakakU, T., 1942. On the effect of the X-chromosome inversions on crossing over in Drosophila virilis. Cytologia, 12, 357-365.

Komai, T. (Jap.), 1946. Two hereditary characters of the human tongue. $\mathcal{J} a p$. Four. Genet., 20, I O-I I.

KomaI, T. (Jap.), I946. On the inheritance of black, yellow and tortoiseshell colour in cats, with special reference to the sperm of the tortoiseshell male. Seibutu, I, I-7.

KonDo, K.,* 1947. On turkey-chicken hybrids, with special reference to their abnormal development. Seibutu, 2, I Io-I I4.

Kondo, N., ${ }^{*}$ 1942. A new Raphanobrassica from the cross, $4 x$-Raphanus sativus $L . \times$ $4^{x}$-Brassica oleracea L. Fap. Four. Genet., 18 , I 26-1 30.

Kondo, N., and Megata, M.,* r 943. Chromosome studies in Aloina. Seiken Ziho, $2,69-82$.

KonDO, Y., 1942. (An induction of polyploid rice plants by treatment with colchicine.) Agric. and Hort., 17, 209-2I I.

Kondo, Y., and KariYa, K., r947. (Diploid progenies obtained from polyploid rice plants.) Agric. and Hort., 22, 557-558. 
Kumazawa, M., and Kimura, M., ${ }^{*}$ i946. Karyotype analysis in the horticultural forms of Lilium maculatum and in the allied species. Chromosome morphology in Lilium, I. Seibutu, I, 73-84.

Kumazawa, M., and Kimura, M.,* 1947. Karyotypes in the Martagon group. Chromosome morphology in Lilium. III. Fap. Four. Genet., Supp. Vol. 1, 100-IO9.

Kumazawa, M., and Kimura, M.,* 1947 . Karyotypes and phylogenetic alterations of SAT-chromosomes in Lilium. Chromosome morphology in Lilium. IV. Fap. Four. Genet., Supp. Vol. I, $110-118$.

Kurabayashi, M. (Jap.), 1946. New karyotype of the genus Trillium. Fap. Four. Genet., 21, 97-98.

Kurabayashi, M. (Jap.), 1948. Differential reactivity of the chromosomes of Paris hexaphylla. Fap. Four. Genet., 23, 22.

Kusunokr, S., 1944. Ueber Chloroplasten-Anomalien bei Kulturen von Nitella sp. und Hydrilla verticillata. Cytologia, I3, 225-236.

Kusunoki, S., 1944. Zur Fortpflanzung der Konjugaten. Cytologia, 13, 297-322.

KuWAdA, Y., and NakamuRA, T., 194. The hydration and dehydration phenomena in mitosis. IV. The chromonemata as natural existence. Cytologia, I2, 14-20.

Kuwada, Y., and Nakamura, T., 1941. Studies of mitosis and meiosis in Tradescantia staminate hairs. Cytologia, 12, 21-43.

Makino, S., I941. Karyological study of gold fish of Japan. Cytologia, 12, 96-i I1.

Makino, S., 194I. The chromosome relation between the two allied species of the Loach (Cobitida, Pisces). Cytologia, I2, 79-82.

MaKino, S.,* 1941. Cytological observations on the maturation and fertilization of the egg in the white mouse, Mus musculus L. Fap. Four. Genet., 17, 13-20.

Makino, S., 1942. Studies on the murine chromosomes. II. Four. Fac. Sci. Hokkaido Imp. Univ., Ser. VI, Zool. 8.

MaKino, S., I942. Artificial induction of meiotic chromosome pairing in the somatic cell of Drosophila virilis. (Cytological studies on D. virilis, Part III.) Cytologia, I2, I 79-1 86.

Makino, S., Niryama, H.,* I 942 . The chromosomes of Scolopendra damnosa L. Koch (Chilopoda). Jap. Jour. Genet., I8, 34-40.

Makino, S., ig43. The chromosomes of the horse (Equus caballus). Chromosome studies in the domestic mammals. I. Cytologia, 13, 26-38.

Makino, S., 1943. Studies on the murine chromosomes. III. A comparative study of chromosomes in 5 species of Rattus. Four. Fac. Sci. Hokkaido Imp. Univ., Ser. VI, Zool. 9 .

Makino, S., 1943. The chromosome complexes in goat (Capra hircus) and sheep (Ovis aries) and their relationship. (Chromosome studies in domestic mammals, II.) Cytologia, I3, 39-54.

Makino, S., and Ozima, Y., i943. Formation of the diploid egg nucleus due to suppression of the second maturation division, induced by refrigeration of fertilized eggs of the carp, Cyprinus carpio. Cytologia, 13, 55-6o.

Makino, S., 1944. The chromosome complex of the pig (Sus scrofa). (Chromosomes studies in domestic mammals, III.) Cytologia, I3, I 70-1 78 .

Makino, S., 1944. Studies on the murine chromosome. IV. The karyotypes of the mole-rat and the harvest-mouse. Cytologia, 13, 237-245.

Makino, S., 1944. Karyotypes of domestic cattle, Zebu and domestic waterbuffalo. (Chromosomes studies in domestic mammals, IV.) Cytologia, 13, $247-264$.

Makino, S. (Jap.), i944. On the sex-chromosomes of Bos taurus, Sus scrofa and Rangifer phylarchus. Fap. Jour. Genet., 20, go.

Makino, S.,* 1946 . On the karyological relationship of the domestic swine and the Japanese wild boar. La Kromosomo, I, I2-17.

Makino, S. (Jap.), i 946 . Additional list of animal chromosomes, I. La Kromosomo, $I, 42-46$. 
Makino, S. (Jap.), 1947. Illustrated monograph of animal karyotypes. I. Pisces. La Kromosomo, 3-4, 1 76-185.

Makino, S., 1947. A study of chromosomes in the two sexes of Hynobius retardatus (an Urodelan) with a consideration on the chromosomes and sex. Four. Fac. Sci. Hokkaido Imp. Univ., Series VI, Zool. Vol. 9, 3, 25I-265.

Makino, S., 1947. Notes on the chromosomes of 4 species of small mammals. (Chromosomes studies in domestic mammals, V.) Jour. Fac. Sci. Hokkaido Imp. Univ., Ser. VI, Zool. Vol. 9, 4, 345-357.

Makino, S., and Niryama, H., I947. A study of chromosomes in Echinoderms. Jour. Fac. Sci. Hokkaido Imp. Univ., Ser. VI, Zool. Vol. 9, 3, 225-232.

MAsima, I., 1947. The number of chromosomes and the nucleolar chromosomes in Linum usitatissimum L. and some allied species. Jap. Four. Genet., Supp. Vol. I, I 22-131.

Masur, K., and Kondo, K. (Jap.), I948. On the intersex in milk goats. Jap. Four. Genet., 23, 24-25.

Matsur, Y., and Makino, S. (Jap.), 1943. A preliminary account on the cytological observations on male hybrids between carp and goldfish. Jap. Jour. Genet., 19, 128-1 29 .

Matsumoto, K.,* 1942. Die Eigenschaft des Erythrozytentyps der Pferde. Jap. Jour. Genet., 18, 74-79.

Matsumura, S.,* 1942. Genetische Studien bei Amaranthus tricolor L. III. Jap. Four. Genet., 18, $261-272$.

Matsumura, S., Mochizuki, A., und Akemine, T.,* 1942. Genetische und zytologische Untersuchungen bei Beta-Arten. II. Colchicininduzierte polyploide pflanzen und ihre Nachkommen bei Beta vulgaris. Seiken Ziho, I, 16-23.

Matsumura, S.,* 1947. Chromosomenanalyse des Dinkelgenoms auf Grund zytogenetischer Untersuchungen an pentaploiden Weizenbastarden. $L a$ Kromosomo, 3-4, II 3-132.

Matsuura, H., and Oxuno, S., 1943. Cytogenetical studies on Begonia. Cytologia, I3, I-I 8 .

MatsuUra, H., 1946. Chromosome studies on Trillium Kamtschaticum Pall. and its allies. XXII. Critical evidence of spiral theory of crossing-over. Four. Fac. Sci. Hokkaido Imp. Univ., Ser. V, 6, 6 I -66.

Meguro, T., 1942. (Colchicine-induced polyploids in sweet potato.) Agric. and Hort., $17,887-888$.

Mrduno, T. (Jap.), 1943. Karyotyp einiger Anemone-Pflanzen. Fap. Four. Genet., I9, I $23-124$.

Mryabayashi, T., 1941. (Polyploid plants induced by colchicine.) A review. Bot. and Zool., 9, 267-278.

Mrzusima, U., 1944. (Some new amphidiploids in Crucifere. I-IV.) Breed. and Hort., 2, 401-404, 441-444, 481-483, 51 5-5 I 6.

Mrzusima, U., 1 944 . (On the study of allo- and autopolyploids induced in Brassica, Sinapis and Raphanus.) Agric. and Hort., 19, 697-700.

Mrzusima, U., 1944. (Haploid parthenogenesis in Brassica and Sinapis.) Agric. and Hort., $19,740-744$.

Mrzusima, U., 1946. (Idem. V-VII.) Breeding and Agriculture, I, 31-32, 67-68, I 9o-I 9 I, 2, 59-6o.

Mrzusima, U.,* I 948 . Study on sexual affinity among rice varieties, Oryza sativa L. I. Analysis of affinity of Japanese, American and Javanese varieties. Seibutu, $3,41-52$.

Monma, E.,* 1941. A study of the chromosome of six species of the Locustide. Fap. Four. Genet., 17, i65-1 70 .

Monma, E.,* 1941. The chromosomes of two species of Euscyrtus (Gryllide, Podoscyrtine). Fap. Four. Genet., 17, 307-309.

Monma, E.,* 1942. Polyploid primary spermatocytes in Phleoba infumata (Acridide). Botany and Zoology, Io, 69-7 ז. 
Monma, E.,* 1942. Notes on the chromosomes of Brachytrupes portentosus (Grylline, Gryllide). Jap. Jour. Genet., 18, 309-31 2.

Monma, E., and Makino, S. (Jap.), i 948 . Morphological changes of chromosomes caused by the reaction of temperature. Fap. Four. Genet., 23, 31 .

Mori, T. (Jap.), 1947. On the extra-chromosomes in Secale cereale L. Fap. Four. Genet., 22, 19.

Mori, T. (Jap.), 1948. Experimental observations on the behaviour of extrachromosomes in the artificial "twin" plants of Secale cereale L. Jap. Jour. Genet., 23, 32.

Morinaga, T., Nagamatsu, T., and Kawahara, E., * 1943 . New linkage relations in rice. Jap. Jour. Genet., 19, 206-208.

Morinaga, T., and Fukushima, E. (Jap.), 1946. Cytogenetic studies on the offspring of some interspecific hybrids in Oryza. Fap. Four. Genet., 21, 35-36.

Morinaga, T., and Kuriyama, H. (Jap.), 1946. On the early advancing behaviour of fertility in the autotetraploid rice plants, with reference to the effects of crossings among different strains of those polyploidal plants upon the fertility behaviour. (A résumé.) Jap. Four. Genet., 2I, $8 \mathrm{I}-83$.

Morita, J., 1942. A contribution to the study of the structure of the salivary gland chromosome in Chironomus. Cytologia, 12, 135-162.

Morrwaki, D., and Oyama, K. (TAKU, U.),* 1947. Manifestation of characters in Drosophila ananasse. I. Date of emergence and its effects. Fap. Four. Genet., Supp. Vol. $1,5^{1-58}$.

Morrya, A.,* 1941. Preliminary note on the chromosome numbers of sugar cane varieties $\mathrm{F}$ i 08 and some others. Jap. Jour. Genet., 17, 62-64.

MorIYA, A. 1943. Contributions to the cytology of Genus Saccharum. II. The chromosome number of Saccharum robustum, indigenous to New Guinea. Cytologia, $13,265-269$.

Morohosi, S., ${ }^{*}$ 1941. Transplantation of optic discs and eye colors in Bombyx mori. II. Fap. Four. Genet., 17,2 I-87.

Moroноsi, S. (Jap.), i 947 . Mutual relation of the developmental processes in the silkworm. Fap. Four. Genet., 22, 20-2 I.

Motegi, A., * r943. Stellungnahme der Ophthalmolog zu den angeborenen Anomalien. Jap. Jour. Genet., 19, 235-243.

Мотомura, I.,* 1947. Vital staining of the cytoplasmic lipoid granules with carcinogenic azo-dyes. Jap. Jour. Genet., 22, $21-22$.

Muroga, H., * 1948. Studies on the linkage in silkworm, Bombyx mori L. I. Chromosome bearing in the linkage group x-be. Jap. Jour. Genet., 23, 35-36.

Muroga, H., 1948. Studies on the linkage in silkworm, Bombyx mori L. II. Chromosome bearing the gene bo. Jap. Four. Genet., 23, 36 .

Nagamatsu, T.,* 1943. Studies on the geographical differentiation of characters in cultivated rice. II. Classification of the cultivated rice varieties by anthocyan pigments. Fap. Four. Genet., 19, 249-257.

Nagamatsu, T. (Jap.), 1946. Cytogenetical studies on Prunus mume. II. Seibutu, I, $271-274$.

Nagao, S., 1941. Cytogenetics in the genus Linum. Fap. Four. Genet., I7, 109-1 6.

NaGaO, S., and KaWamura, T., * 1942 . Experiments on emasculating rice florets by hot water method. Fap. Jour. Genet., 18, 58-68.

NaGao, S., and Masima, I.,* ${ }^{*}$ r 944 . Studies on the chromosomes of Chelidonium majus. III. Variation of karyotypes found in plants coming from different localities. Fap. Jour. Genet., 20, 59-63.

NaGaO, S., and Takahashi, M., * 1946 . On the nature of genes for the dwarf of rice plant. (Genetical studies on rice plant. VIII.) Seibutu, 1, 27-36.

Nakajima, G., 1942. Cytological studies in some flowering diøcious plants, with special reference to the sex chromosomes. Cytologia, 12, 262-27o.

Nakajima, G., 1946. Multiploids of sweet potatoes made by colchicine treatment. Proc. Crop. Soci. Jap., 15, 25-27. 
Nakajima, G., 1947. The tetraploid plants in Quamoclit raised by the colchicine method. Fap. Four. Genet., 23 (in press).

Nakamura, D.,* ${ }^{*}$ 1943. Einige Beobachtungen bei der Bastardbefruchtung und -furchung in Kombination von Hynobius nebulosus (q) und Pseudosalamandra kimurai ( $\left.\sigma^{3}\right)$. Jap. Jour. Genet., 19, 266-274.

Nakamura, K.,* 1946. Chromosome of Galloisiana nipponensis (Orthoptera). La Kromosomo, I, 29-3o.

Nakamura, M.,* I 942 . Cytological studies in the genus Citrus. III. Further data on the chromosome numbers. Four. Hort. Assoc., 13, 30-40.

Nakamura, M., 1943. Cytological and ecological studies on the genus Citrus, with special reference to the occurrence of sterile pollen grains. Mem. Fac. Sci. and Agri. Taihoku Univ., Phytotechny No. 5.

Naкатомі, S., 1942. On the polyploid cotton plant induced by the treatment with colchicine to the interspecific hybrids $\left(\mathrm{F}_{1}\right)$. Proc. Crop. Soci. Fapan, I4, I I 3 -I I 8 .

Nakatomi, S., 1943. (Breeding and genetics in cotton.) Kwagaku, 13, 245-248.

Niryama, E. (Jap.), ig46. Chromosomes of some echinoderms. Fap. Four. Genet., 21,53 .

Niryama, E., 1946. Chromosomes of a phasmid, Entria okinawensis shiraki. Contrib. No. 19o, Zool. Inst. Fac. Sci. Hokkaido Imp. Univ. Sapporo.

Niryama, H.,* I94I. Chromosomes of the crayfish, Cambarus clarkii, introduced from America. Jap. Jour. Genet., I7, 304-306.

Niryama, H., I941. The X-O type of sex-chromosome found in Ovalipes punctatus (de Haan) (Crustacea : Decapoda). Fap. Four. Genet., I7, 4 I-45.

Niryama, H. (Jap.), i942. On the multiple chromosome involving the $\mathrm{X}$ found in three species of beetles belonging to the Buprestida. Jap. Jour. Genet, , $88,56-58$.

Niryama, H., 1944. A study on chromosomes in Hydra. Cytologia, 13, 204-209.

Nishina, Y., and Moriwaki, D.,* 194I. An experiment of the grouping of genes in Drosophila melanogaster. Fap. Four. Genet., I7, I 7 I-I 74.

Nishiyama, I.,* 194I. Cytogenetical studies on Avena. IV. Distorted Mendelian ratios due to differential fertilization. Fap. Four. Genet., I7, 247-264.

Nishiyama, I., * 194 I. Studies on artificial polyploid plants. V. The breeding of long fibered varieties by doubling the chromosome number in hemp. Bot. and Zool., 9, 69-75.

Nishiyama, I., * I 942 . Studies on artificial polyploid plants. VI. On the different growth of the diploid and tetraploid radish in the winter season. Four. Hort. Assoc. Japan, 13, 245-25I.

Nishiyama, I., and Kondo, N., ${ }^{*}$ 1942. Chromosome studies in tropical plants. I. Seiken Ziho, $I, 26-28$.

Nishiyama, I., Sogo, Y., and Mikata, Y.,* 1942. Studies on artificial polyploid plants. VII. The effect of colchicine on chromosome doubling in some vegetable plants. Bot. and Zool., ro, I I I 9 -I I 2 I.

Nishiyama, I., Yamada, I., and Kondo, N. (Jap.), 1944. Cytological studies of Artocarpus communis Forst. Jap. Jour. Genet., 20, 76-77.

Nishiyama, I. (Jap.), 1946. On the genus cross between autotetraploid plants of Raphanus and Brassica. Fap. Four. Genet., 2I, II 5 .

Nishiyama, I., Yamada, I., Furusato, K., and Kondo, N., * 1946 . Chromosome studies in Saccharum. Fap. Four. Genet., 21, 56-57.

Nishiyama, I.,* 1947. Studies on the sugar cane. III. Wild sugar canes in Asia and their significance in the point of view of cane-breeding. Seiken Ziho, 3, Part 2, 54-62.

Nishiyama, I., et al.,* 1947 . Studies on the sugar cane. IV. Chromosome numbers of wild sugar canes in Micronesia. V. Chromosomes studies in some sugar cane hybrids. Seiken Ziho, 3, Part 2, 63-76.

Nishiyama, I., and Matsubayashi, G. (Jap.), i947. A list of induced polyploids in the plant. (A review.) Seiken Ziho, 3, Part 3, 152-171. 
Nishiyama, I., et al., 1948. (Studies on the yield ability of an induced autotetraploid radish.) Breed. and Agr., 3, 69-7I.

NodA, K. (Jap.), 1946. Chromosome studies in clover plants. Fap. Four. Genet., $2 I, 93-96$.

Nocusa, S., * r 1943 . On the chromosomes of four species of the Cyprinida (Pisces). Jap. Four. Genet., 19, 282-287.

Noguti, Y., and Sugawara, T., 1942. (Some economical characteristics of autotetraploids in Fagopyrum and Helianthus.) Kwagaku, 12, 42-46.

Nozawa, K.,* 1943. Genetics of Thecamaba. I. Heritable shell abnormalities found in Arcella hemispherica and Centropyxis aculeata. Jap. Jour. Genet., I9, I 89-199.

Noz.AWA, K., 1944. Studies on the nucleo-plasmic ratio. III. The ratio in the ciliate, Glaucoma pyriformis. Cytologia, 13, 360-368.

Oguma, K. (Jap.), i 946 . Karyotype and phylogeny of Mantis. La Kromosomo, I, I-5.

()HGAKI, M. (Jap.), 1948. A study on the salivary gland chromosome of Drosophila virilis with a microphotometer. Jap. Jour. Genet., 23, $4^{\circ}$.

Онмасні, F., ${ }^{*}$ I 942 . On female intersexes in Homoogryllus japonicus de Haan. Jap. Four. Genet., I8, I 109 -1 I 3 .

OiкAwa, K. (Jap.), I 942. Chromosome number of Adoxa Moschatellina L. Jap. Jour. Genet., $18,1.57-158$.

Oinuma, T., ${ }^{*}$ 1946. Karyotype analysis of Liriope and Ophiopogon. La Kromosomo, $2,7 \mathrm{I}-75$.

Oкuma, K. (Jap.), 1942. On the amphidiploid between Nicotiana suavealens and N. glauca. Jap. Four. Genet., I8, 104-105.

Okuno, S. (Jap.), i 942 . On the abnormal meiosis in Begonia Rex. Fap. Four. Genet., $18,70-7 \mathrm{I}$.

Oкuno, S., 1944. The secondary association of meiotic chromosomes in Oryza sativa L. Jour. Fac. Sci. Hokkaido Imp. Univ., Ser. V, Vol. 3, 2 I 5-220.

Okuno, S., 1946. On the artificial induction of polyploid pollen grains by treatment with low temperature. La Kromosomo, 2, 64-70.

Omura, S. (Jap.), 1948. Selective fertilization in Bombyx mori (3). Fap. Jour. Genet., $23,40-4$ I.

Ono, H., I 941 I. Intergeneric hybridization in Cichoriea. V. Variation in karyotypes and fertility of Crepidiastrixeris denticulatoplatyphylla. Cytologia, II, 338-352.

Ono, H., 1943. Intergeneric hybridization in Cichoriee. VI. A hybrid of Paraixeris denticulata and Lactuca squarrosa. Cytologia, 13, 61-72.

ONo, H.,* 1946. Secondary pairing and residual pairing. Seibutu, I, 224-227.

Ono, H. (Jap.), 1948. A hybrid between Crepidiastrum keiskeana and Paraixeris denticulata. Jap. Jour. Genet., 23, 4I.

ONo, T. (Jap.), ig48. Some properties of tetraploid barley. Jap. Jour. Genet., $23,4^{1-42 .}$

ONo, T., $194^{8}$. (Breeding of hop, with special reference to an induction of polyploids.) Seibutugaku Gyoseki, 2, 1-10.

Osato, S., et al. (Jap.), 1948. Study on twins (3). Jap. Jour. Genet., 23, 43-44.

Osima, T. (Jap.), 1947. The X-chromosomes in the hybrid of the two sub-species of Drosophila virilis, texana and virilis. Fap. Four. Genet., 22, 27-28.

SAKaI, B. (Jap.), I946. Somatische Chromosomenzahl einiger Gattung der Untelfam. Iridodea. Jap. Jour. Genet., 2I, $4^{\text {o. }}$

SAKAI, K., ${ }^{*}$ 194I. Diurnal periodicity of somatic mitosis in the root tips of several (rop plants. Fap. Jour. Genet., I7, 35-40.

SATo, D., 1941. A diploid plant with only one nucleolus and its bearing on the balance hypothesis of nucleolar chromosome. Bot. Mag. Tokyo, 55, 159-163.

SATô, D., I 942 . Karyotype alteration and phylogeny. V. New types of SATchronosomes in Nothoscordum and Nerine. Cytologia, 12, 1 70-1 78.

SATô, D., * 1942. Karyotype alteration and phylogeny in Liliacea and allied families. Jap. Jour. Bot., 12, 57-161. 
SAtô, D.* (Jap.), 1943. Karyotype analysis in the tropical plants. I. Liliacee and its allied families. Fap. Four. Genet., 19, 124-1 25.

SATô, D., 1944. The evolution of basikaryotypes in Scilla permixta with special reference to the genome. Cytologia, 13, 194-203.

SAtô, D., * I 946 . Basikaryotype analysis in Brodiea uniflora. La Kromosomo, $t$, 24-28.

SAtô, D. (Jap.), 1947. Origin and phylogeny of karyotypes in Agavacee. Jap. Four. Genet., 22, 28.

SAtô, D. (Jap.), r948. The karyotypes and phylogeny in Zingiberales. Fap. Four. Genet., 23, 44-45.

SAto, Y., and Yamaguchi, S. (Jap.), 1942. On race differentiation in Abies. Fap. Four. Genet., 18, 7 I-74.

Shimamura, T., and Kobayashi, T. (Jap.), 1948. Artificial polyploid of Sesamum orientalis L. Jap. Jour. Genet., 23, 45-46.

Shimotomai, N., and Huziwara, Y., I942. Zytologische Untersuchungen über Aster, Gymnaster, Kalimeris und Heteropappus aus Japan. Cytologia, 12, 206-2 I 8.

Shimotomai, N. (Jap.), 1947. The polyploidy in the genus Artemisia. Fap. Four. Genet., 22, 29-30.

Shimoтомai, N. (Jap.), 1947. The artificially produced polyploids in Chrysanthemum cinerariafolium visani. Jap. Jour. Genet., 22, 30.

Shimotomal, N., and Inoue, S. (Jap.), r948. Comparative studies of the diploid and tetraploid forms of Gymnaster Savatieri (Makino) Kitamura. Jap. Jour. Genet., 23, 46 .

Sigemoro, E., I947. Morphological observations of abnormal follicles in mature ovaries of the Norway rat, Rattus norvegicus. Four. Fac. Sci. Hokkaido Imp. Univ., Ser. VI, Vol. IX, 3, 233-24I.

Sigenaga, M., 1944. Experimental studies of abnormal nuclear and cell divisions. I. Observation with living cells of the effects of neutral salts and heavy metal salts. Cytologia, 13, 380-404.

Simodaira, M. (Jap.), r947. Studies of linkage in the silkworm. III. Inheritance of haimonkata type. Fap. Four. Genet., 22, 87-88.

Sinke, N., Iijima, M., and Hiraoka, T., I 947 . A histochemical study of Lilium anthers. Mem. Coll. Sci. Kyoto Univ., Ser. B, Vol. XIX.

Sinoto, Y., and YuAsA, A., I94I. Karyological studies in Saccharomyces cerevise. Cytologia, II, 464-472.

Sinoto, Y., and SATô, D., I942. Cytogenetical studies on Tricyrtis. III. Polybasic forms in Tricyrtis formosana. Cytologia, 12, 289-30I. IV. Basikaryotype analysis in hybrids of Tricyrtis hirta and T. formosana. Cytologia, 12, 302-312.

Sinoto, Y., I944. Ueber die Struktur des X-chromosoms und die TrabantChromosomen an Homeogryllus japonicus. Cytologia, 13, 2 I 0-2 I4.

Soeda, T., 1944. A cytological study on the genus Sedum, with remarks on the chromosome numbers of some related plants. Four. Fac. Sci. Hokkaido Imp. Univ., Ser. V, Vol. V, 3, 22 I-23I.

SoEdA, T., 1944. Chromosome structure and behaviour in some plants. I. Chromosomes of Diphylleia Grayi Fr. Schm. Jour. Fac. Sci. Hokkaido Imp. Univ., Ser. V. Vol. V, 3, 233-248.

SoEdA, T.,* (Jap.), 1946. The effect of some chemicals on inducing of polyploidy. (Preliminary note.) Jap. Jour. Genet., 21, 44-45.

Suginara, Y. (Jap.), 1947. The chromosome numbers in Gymnosperms. Jap. Jour. Genet., Supp. Vol. 1 , 132-1 38 .

SugruRA, T., I94I. A list of chromosome numbers in Angiospermous plants. VII. Proc. Imp. Acad. Tokyo, 17.

Sugrura, T., 1942. Studies on the chromosome numbers in Campanulacee. I. Campanuloider-Campanulea. Cytologia, 12, 4 18-434.

Strgrura, T., I944. Studies on the chromosome numbers in higher plants. VI. Cytologia, 13, 352-359. 
Surta, N., r943. Studies on the male gametophyte in Angiosperms. VII. The mechanism of the karyokinesis and cytokinesis in the pollen tube. Cytologia, I3, I I8-1 I9.

Sutô, T. (Jap.), 1943. Extra chromosomes in Zea Mays L. Jap. Jour. Genet., 19, I3 I-I 33 .

Surô, T., r944. Meiotic chromosome behaviour in Populus nigra L. and Toisusu cardiophylla Kimura. Jour. Fac. Sci. Hokkaido Imp. Univ., Ser. V, Vol. V, 3, 249-263.

Sutô, T. (Jap.), 1948. Gene analysis in maize. IV. On the lethality of the dominant homotype Tp-gene. Jap. Four. Genet., 23, 50-5 I.

Suzukr, E., I941. Cytological studies of sugar cane. I. Observations on some POJ varieties. Cytologia, $I I, 507-514$.

SuzukI, K., 1941. Development of Plasmodium precox in Culex pipiens pallens. Cytologia, $I 1,526-536$.

SuzukI, K.," r942. A new mutant in the silkworm, "crayfish-pupa" and its linkage. Fap. Jour. Genet., 18, 26-33.

Syakudo, K., ${ }^{*}$ I 947 . Studies of quantitative inheritance (I). Rice, Oryza satiav L. (a) Inheritance of the length of panicles and the quantitative function of the causal genes in their length determination. I. On the quantitative function of the gene $P_{1}$. (b) Inheritance of the height of culms and the quantitative function of the causal genes in their length determination. 1. On the quantitative function of the gene $\mathrm{H}_{1}$. Jap. Jour. Genet., Supp. Vol. I, 28-48.

TAKasaki, T.,* (Jap.), r942. Cell-lethals in the silkworm, Bombyx mori L. Jap. Jour. Genet., I8, 186-1 89 .

TAKASAKI, T., and TAZIMA, Y. (Jap.), 1944. Behaviour of the chromosomes in monosomic and trisomic silkworms. Jap. Jour. Genet., 20, 75-76.

TAKENAKA, Y.,* I941. Further reports of cytological and genetic investigations of Rumex acetosa L. IV. On offspring of a diploid intersexual plant involving chromosome fragments. Fap. Four. Genet., $17,28-3 \mathrm{I}$.

Takizawa, S., r 944 . Chromosome studies in the genus Acer L. II. Meiosis abnormalities in PMCs of A. japonicum Thunb. var. typicum Schw. Jour. Fac. Sci. Hokkaido Imp. Univ., Ser. V, Vol. V, 3, 263-293.

TAKIZAWA, S. (Jap.), 1948. Meiosis in triploid Fritillaria camschatcencis. Jap. Jour. Genet., 23, 53-54.

Tanaka, N. (Jap.), 1946. Structural hybridity in the genus Carex. Fap. Four. Genet., 2I, 58-59.

TANaka, Y. (Jap.), 1948. Breeding of Chinese Tussar silkworm, Antherea pernyi Guér. Jap. Jour. Genet., 23, 54-55.

TAtEBE, T.,* 1943. Studies on the inheritance of fruit shape in the egg-plant. Jap. Jour. Genet.; 19, 57-74.

TAteBE, T., ${ }^{*}$ r944. Further studies on inheritance of color in Solanum melongena L. Fap. Four. Genet., $20,1-7$.

TAtEBE, T., ${ }^{*}$ 1947. On the behaviour of incompatible pollen in the wild radish. Fap. Jour. Genet., Supp. Vol. I, 97-99.

TAtuno, S., 1941. Zytologische Untersuchungen über Lebermoose von Japan. Jour. Sci. Hiroshima Univ., Ser. B, Div. 2, 4, 75-187.

TAtuno, S. (Jap.), 1943. Geschlechtschromosomen bei Frullania taiheizana Horikawa. Fap. Four. Genet., 19, ror.

Tatuno, S. (Jap.), 1948. Polyploidie von Dumortiera hirsuta und Verbreitung in Hokuriku und Provinz Nagano. Jap. Jour. Genet., 23, 55.

TAzima, Y., ${ }^{*}$ I 942 . A case of the mosaicism in the silkworm egg, probably due to a recessive mutation. Fap. Four. Genet., 18, 305-308.

TAzima, Y. (Jap.), r944. Behaviour of the sex-chromosomes in the tetraploid female of silkworm, Bombyx mori. Fap. Four. Genet., 20, 74-75.

TAzima, Y. (Jap.), r948. Translocation involving $\mathrm{Z}$ and $\mathrm{W}$ chromosomes of the silkworm and its breakage. Jap. Jour. Genet., 22, 55-56. 
Terada, J., and Masuda, K., 1943. (On the parthenocarpy of triploid watermelons.) Agr. and Hort., I8, 5 I I-512.

Tokunaga, C. (Jap.), 1948. A case of complicated genetic behaviour found in Aphiochata sp. (Dipt.). Fap. Four. Genet., 23, 56 .

TuzrTA, M.,* ${ }^{\text {I } 947 . ~ I n h e r i t a n c e ~ o f ~ a ~ n e w ~ m o s a i c ~ s i l k w o r m ~ p r o d u c e d ~ b y ~ m u t a t i o n . ~}$ Fap. Four. Genet., Supp. Vol. I, 76-8o.

U, N., and Huziwara, H.,* ${ }^{*}$ 1947. On an autotriploid plant of Viola tricolor L. var. hortensis DC. Fap. Four. Genet., 22, 77-81.

U, N., and Huziwara, H. (Jap.), I947. Karyologische Beobachtungen bei $F_{1}$ Bastarden von Diploid $\times$ Tetraploid der Primula malacoides Frand. Fap. Four. Genet., 22, 95-96.

Uchida, T., and Hanaoka, K., I94I. Sex differentiation in parabiotic twins of Hynobius retardatus and $H$. lichenatus. Annot. Zool. Fapon, Vol. XX, 3, 123-126.

UchidA, T., I943. Reciprocal translocation of testicular grafts in two Salamander species. Cytologia, I3, 73-86.

UchikaWA, I., I 94 I. Genetic and cytological studies of speltoid wheat. II. Origin of speltoid wheat. Mem. Coll. Agr. Kyoto Imp. Univ., No. 5o.

Uchikawa, I., 1943. Genetic and cytological studies of speltoid wheat. V. Origin of short-compactoid wheat. Mem. Coll. Agr. Kyoto Imp. Univ., No. 55.

Uahikawa, I. (Jap.), 1943. Cytological studies in Japanese bamboo. Fap. Four. Genet., I9, I I 2-I I 3.

WADA, B., I 944 . Studien zur Kausanalyse der Mitose. I. Die Mitoseablaufskurve bei den Tradescantia-Haarzellen. Cytologia, 13, 323-336.

YAKUWA, K., 1944. Cytological studies on autotetraploid Brassica chinensis L. Cytologia, $13,162-169$.

YAKUWA, K. (Jap.), 1944. On the behaviour of extra chromosomes of Secale cereale L. Fap. Four. Genet., 20, 72-73.

Yamada, I. (Jap.), 1943. The sex chromosomes of Cannabis sativa L. Seiken Ziho, $2,64-68$.

YAMASAKI, Y. (Jap.), 1947. Studies on growth of the embryo transplanted between the different species and genera in some cereal crops. Fap. Four. Genet., 22, 33-34.

YAMASAKI, Y.,* 1947. Local difference in the occurrence of twin plants and the accompanying chromosome aberrations in common wheat. Fap. Four. Genet., 22,6 I -66.

Yamashina, Y., i 942. A revised study of the chromosomes of the Moscovy duck, the domestic duck and their hybrid. Cytologia, I2, I63-169.

Yamashina, Y.,* 1942. On the hybrid between the domestic fowl, Gallus gallus var. domesticus and the common pheasant, Phasianus colchicus. Fap. Four. Genet., I8, $23 \mathrm{I}-253$.

Yamashina, Y., 1943. Cytological researches on hybrids in the family Phasianida. Four. Fac. Sci. Hokkaido Imp. Univ., Ser. VI, Zool. 8, 308-386.

Yamashina, Y., 1944. Karyotype studies in birds. I. Comparative morphology of chromosomes in seventeen races of domestic fowl. Cytologia, 13, 270-296.

Yamashina, Y.,* ${ }^{1} 946$. The chromosome of the cuckoo, the budgerigar, the little ringed plover and the Chinese bamboo pheasant. La Kromosomo, I, 18-23.

Yamashina, Y.,* 1946. Chromosomes of three species of the Phasianide (Galli.). Seibutu, I, 42-47.

Yamashina, Y., and Makino, S.,* i 946 . A study on the chromosomes of pigeon and doves. Seibutu, I, 92-Ioo.

Yamashita, K., * 1943. Offsprings of triploid wheat hybrids. Seiken Ziho, 2, $4^{-1} 3$.

Yamaura, A., ${ }^{*}$ I 942 . Heredity in the movability of the human tongue. Fap. Four. Genet., I8, 99-IOI.

Yamaura, A.,* 1947. On the multiple births in families with many children. Jap. Jour. Genet., Supp. Vol. I, 72-7,5. 
YASUI, K., I94I. Cytogenetic studies in artificially raised interspecific hybrids of Papaver. VIII. F 1 plants of $P$. bracteata $\times$ P. lateritium. Cytologia, II, 452-463.

YASUI, K., I94I. Diploid bud formation in a haploid Oryza with some remarks on the behaviour of Nucleolus in mitosis. Cytologia, $I I, 515-525$.

YASUI, K., I94I. On the extrusion of nuclear granules and their reversible swelling in plant cells, with special reference to vacuole formation in the cytoplasm. Cytologia, I2, 83-95.

YASUI, K., I 942. Cytogenetic studies in Melandrium album. II. Di- tetra- mixoploid obtained by colchicine treatment. Cytologia, 12, 469-478.

YAsur, K.,* 1944. On the multinucleate state in the early stage of the ontogeny in the flowering plants (Preliminary note.) Jap. Jour. Genet., 20, 20-24.

YAsur, K., ${ }^{*}$ (Jap.), r 946 . On polyploid plants of the genus Sequoia. Fap. Jour. Genet., 2I, 9-10.

YASUZUMI, G., KITA, T., and OKAzAKI, A. (Jap.), 1948. On the molecular structure of salivary gland chromosomes. II. Jap. Jour. Genet., 23, 59-6o.

Yosida, T.,* 1946. Chromosome studies in the Coleoptera. II. Abnormal meiotic divisions in Synonycha grandis Thunberg. Seibutu, I, 218-223.

Yosida, T., 1947. A chromosomal survey in 20 species of heteropteran insects, with special reference to the morphology of sex chromosome. (2). Contr. No. 193, Zool. Inst. Fac. Sci, Hokkaido Imp. Univ.

Yosida, T., 1947. Unusual type of nucleolus observed in a bug, Acanthocoris sordidus. Four. Fac. Sci. Hokkaido Imp. Univ., Ser. VI, Vol. 9.

Yosida, T. (Jap.), 1948. Chromosomal differentiation in the allied species of Epilachna (Coleoptera). Jap. Jour. Genet., 23, 61-62.

Yosida, T., and Makino, S. (Jap.), i 948 . Morphological changes of chromosomes due to ultra short wave in Podisma (Acridide). Jap. Jour. Genet., 23, 62-63.

Notz.-English summaries of selected papers from this list will appear in a later number of Heredity. 